\title{
Antioxidative Activity and Chemical Characteristics of Cordycepin-enriched Cordyceps militaris JLM0636 Powder
}

\author{
Hee-Young Ahn', Jae-Young Cha ${ }^{2}$, Yong-Kee Jeong ${ }^{3}$ and Young-Su Cho ${ }^{3}$ * \\ ${ }^{1}$ Department of Medical Biosciences, Graduate School, Dong-A University, Busan 604-714, Korea \\ ${ }^{2}$ Technical Research Institute, Daesun Distilling Co, Ltd, Busan 619-951 \\ ${ }^{3}$ Department of Biotechnology, Dong-A University, Busan 604-714, Korea
}

Received January 8, 2013 /Revised February 20, 2013 /Accepted February 21, 2013

\begin{abstract}
The antioxidative activity and bioactivity of water, ethanol, and methanol extracts from Paecilomyces japonica (PJ), Cordyceps militaris (CM), and cordycepin-enriched C. militaris JLM0636 (CMa) were tested in in vitro experimental models. The PJ water extract showed the highest extraction yield (42.53\%). The highest content of phenolic compounds and flavonoids were found in the water extract of PJ, $2.72 \%$ and $1.73 \%$, respectively. The major minerals were $\mathrm{K}, \mathrm{Mg}$, and $\mathrm{Ca}$. The water extracts of PJ also showed the highest DPPH free radical scavenging activity and reducing power. Linoleic acid peroxidation and antioxidative activities were strong in $\mathrm{CM} \alpha$. The methanol extracts of PJ showed the highest inhibition activity against tyrosinase. Fibriolytic activity was higher in $\mathrm{CM} \alpha$ than in $\mathrm{CM}$. These results may provide basic data to understand the biological activities of bioactive materials derived from $\mathrm{CM} \alpha$ for the development of functional foods, cosmetics, and antithrombotics.
\end{abstract}

Key words : Paecilomyces japonica, Cordyceps militaris, antioxidative activity, cordycepin, fibriolytic activity

\section{서 론}

인간의 체내 대사과정 중 산화반응에 의해 생성된 자유라디 칼은 비공유 전자(unpaired electron)를 갖고 있는 분자이기 때문에 불안정하여 세포구성 성분들과 쉽게 반응하게 되고 비선택적이고 비가역적인 손상을 일으키므로 노화, 암, 동맥 경화증, 염증, 뇌질환과 심혈관질환, 신장질환, 자기면역질환 등의 각종 질병을 일으키는 원인으로 알려져 있다[11]. 이러한 산화적 손상을 억제 할 수 있는 플라보노이드, 폴리페놀이나 카로티노이드를 비롯한 다양한 천연물 유래의 항산화 성분을 많이 함유하며 안전하고 강력한 생리적 효능을 갖는 천연 항 산화제의 탐색과 개발이 절실히 요구되고 있다[16].

동충하초는 겨울에는 벌레 상태로 있다가 여름이 되면 버섯 이 된다는 뜻에서 유래한 이름으로 주로 살아있는 곤충의 몸 에 침입하여 죽게 한 다음, 그 기주의 영양분을 이용하여 자실 체를 형성하는 곤충 기생성 균의 일종으로, 곤충이나 절지동물, 균류 또는 고등 식물의 종자에 기생하는 모든 균류를 총칭한다. 전 세계적으로 약 100 속 750여 종이 분포되어 있으며, 그 중에 서 대표적인 동충하초 속으로는 완전세대의 유성생식 기관으

\footnotetext{
*Corresponding author

Tel : +82-51-200-7586, Fax : +82-51-200-7505

E-mail : choys@dau.ac.kr

This is an Open-Access article distributed under the terms of the Creative Commons Attribution Non-Commercial License (http://creativecommons.org/licenses/by-nc/3.0) which permits unrestricted non-commercial use, distribution, and reproduction in any medium, provided the original work is properly cited.
}

로 자낭균류(Ascomycetes)의 맥각균과(Clavicipitaceae)에 속 하는 Cordyceps 속과 불완전균류의 Paecilomyces 속, Torrubiella 속 및 Podonectria 속이 대표적이다. 넓은 범위의 동충하초 속 이 있지만 모든 종류가 약용으로 사용되는 것은 아니며 그 대표적인 것은 Paecilomyces japonica (P. japonica)와 Cordyceps militaris (C. militaris)이다. P. japonica 는 국내에서 고유하게 개발된 품종으로 눈꽃 동충하초라 부르고 나방류의 곤충과 애벌레, 번데기등을 기주로 하여 기생하며 항암효과, 면역증 강효과, 항 피로효과, 항 스트레스효과, 항 노화효과, 미백효과 등이 보고되고 있다[27]. 또한 C. militaris 는 번데기 동충하초 라 부르며 나비목의 번데기에 기생하는 자실체와 번데기의 복합체로 P. japonica 와 마찬가지로 면역증강활성, 항암활성, 항바이러스효과 및 항염증 효과 등 다양한 생리활성이 보고 됨에 강장 식품 혹은 강장제로 폭넓게 사용되고 있다[1]. 이처 럼 동충하초는 다양한 효능이 있는 것으로 알려지고 있어서 만성 생활습관병이나 난치병의 예방 및 완화제로서의 개발가 치가 높은 것으로 기대된다. C. militaris로부터 분리된 천연 항생 물질인 cordycepin (3'-deoxyadenosine)은 아데노신 리 보오스 잔기의 3 번째 탄소에 산소가 결핍된 구조로 nucleoside의 대사물질이다. Cordycepin의 생리 기능으로는 DNA와 $\mathrm{RNA}$ 의 합성 억제, 항당뇨 작용[20], 고지혈증 개선작용[14] 및 혈소판 응집억제작용[10]이 보고되었다.

따라서 본 연구는 P. japonica, C. militaris, 육종에 의해 cordycepin 함량을 높인 C. militaris JLM0636의 항산화 활성과 생리활성 물질을 탐색하기 위하여 용매별로 추출해 그 효능을 알아보고자 본 실험을 실시하였다. 


\section{재료 및 방법}

\section{실험재료}

본 실험에 사용한 동충하초 동결건조 분말은 2011년산으로 청원농산(김해, 경남)으로부터 P. japonica와 C. militaris의 육종 에 의해 cordycepin 함량을 높인 C. militaris JLM 0636 분말을 직접 제공받아 실험재료로 사용하였다.

\section{시료의 추출조건 및 수율}

수용성 추출물을 얻기 위하여 P. japonica, C. militaris, $C$. militaris JLM0636 분말 $100 \mathrm{~g}$ 을 각각 취해 10 배의 정제수를 가한 후 $40^{\circ} \mathrm{C}$ 항온수조에서 3시간씩 교반 하면서 3회 반복 추출하였으며, $95 \%$ 에탄올 및 $95 \%$ 메탄올 용매를 수용성 추출 물과 동일한 방법으로 추출한 후 추출액을 모아 여과지 (Whatman No.2)로 여과시켜 얻은 여액을 감압 농축(Büchi Rotavapor R-215, Flawil, Switzerland)하여 각각의 용매를 제 거시킨 후 동결건조(Eyela FUD-2100, Tokyo Rikakikai Co., Tokyo, Japan)하여 추출 수율(\%)을 구하였다.

\section{페놀성 화합물 함량 측정}

페놀성 화합물의 함량은 각 용매별 추출물 시료에 Folin-ciocalteu's phenol reagent를 이용한 Folin-Denis 법[29] 으로 비색시켜 spectrophotometer (Hitachi U-2900, Tokyo, Japan)로 $760 \mathrm{~nm}$ 에서 흡광도를 측정하였다. 이 때 함량은 $\tan -$ nic acid를 일정 농도 $(0-500 \mathrm{\mu g} / \mathrm{ml})$ 로 하여 시료와 동일한 방 법으로 측정한 표준곡선으로부터 계산하였다.

\section{Flavonoid 함량 측정}

Flavonoid 함량은 Jia 등의 방법[15]에 따라 각 시료의 추출 용매별 농도에 정제수와 $5 \% \mathrm{NaNO}_{2}$ 용액 및 $10 \% \mathrm{AlCl}_{3}$. $6 \mathrm{H}_{2} \mathrm{O}$ 를 잘 혼합하여 반응시킨 용액을 spectrophotometer (Hitachi U-2900)로 $510 \mathrm{~nm}$ 에서 흡광도를 측정하였다. 이 때 함량은 표준 물질로서 (+)-catechin hydrate을 일정 농도(20 $200 \mathrm{\mu g} / \mathrm{ml}$ )로 시료와 동일한 방법으로 측정하여 작성한 표준 곡선으로부터 계산하였다.

\section{지방산 조성 분석}

지방산 분석은 Garces 및 Mancha 방법[22]으로 각 시료 분 말의 지질을 chloroform 및 methanol 혼합액(2:1)으로 추출하 였다. 추출된 지질 용액에 methanol: $\mathrm{HCl}(5: 1, \mathrm{v} / \mathrm{v} \%)$ 용액으 로 methylation 한 후 hexane으로 지방산 methylester를 추출 하여 Omega-Wax capillary column $(30 \mathrm{~m} \times 0.25 \mu \mathrm{m}$, Supelco, USA)을 사용하여 Gas chromatography (GC-17A, Shimazdu, Koyto, Japan)로 지방산을 분석하였다. 지방산 분석 결과는 각 지방산 표준물질과 동일한 retention time에 검출된 것으로 하였으며, 이때 검출된 총 지방산의 면적에 대한 각 지방산의
면적 비율 $(\%)$ 로 나타내었다.

\section{미네랄 함량 측정}

미네랄 함량은 $\mathrm{AOAC}$ 분석 방법[1]에 준하여 측정하였다. 즉, 각 시료 분말 $1 \mathrm{~g}$ 을 정확히 취해 $550^{\circ} \mathrm{C}$ 에서 3 시간 회화 시킨 후 $6 \mathrm{~N} \mathrm{HCl}$ 에 용해시켜 완전히 산분해시켜 수욕상에서 산을 완전히 제거하고, 이 건고물에 $3 \mathrm{~N} \mathrm{HCl}$ 를 가하여 여과한 후 원소 종류에 따라 각각 일정비율로 희석하여 원자흡광 분 광광도계(Analyst 300, Perkin Elmer, Norwalk CT, USA)를 이용하여 측정하였다.

\section{$\mathrm{DPPH}$ 에 의한 항산화 활성 측정}

항산화 활성 측정은 Blois 방법[4]에 따라 각 용매 추출물 분말을 $0.01,0.05,0.1,0.5$ 및 $1 \%$ 농도로 만든 시료 용액에서 $a, a^{\prime}$-diphenyl- $\beta$-picrylhydrazyl (DPPH) free radical scavenging 활성을 spectrophotometer (Hitachi U-2900)로 $528 \mathrm{~nm}$ 에 서 흡광도를 측정하여 시료 첨가구와 무첨가구의 흡광도차를 백분율 $(\%)$ 로 표시하였다. 이때 활성 비교는 합성 항산화제 butylated hydroxytoluene (BHT)를 0.05\% 농도로 첨가하여 시료와 동일한 방법으로 흡광도를 측정하였다.

DPPH radical scavenging activity (\%)

$=[1-($ sample absorbance $528 \mathrm{~nm}) /$ control absorbance 528 $\mathrm{nm}] \times 100$

\section{$\mathrm{Fe} / \mathrm{Cu}$ 환원력 측정}

$\mathrm{Fe}$-환원력 측정은 $\mathrm{Zhu}$ 등의 방법[33]에 따라 각 용매 추출 물 $0.01,0.05,0.1,0.5$ 및 $1 \%$ 농도의 시료 용액에 $0.2 \mathrm{M}$ sodium phosphate buffer $(\mathrm{pH}$ 6.6) 및 $1 \%(\mathrm{w} / \mathrm{v})$ potassium ferricyanide $\left[\mathrm{K}_{3} \mathrm{Fe}(\mathrm{CN})_{6}\right]$ 를 혼합하여 $50^{\circ} \mathrm{C}$ 에서 반응 시키고 $10 \%$ trichloroacetic acid (w/v) 상층액에 증류수 및 $0.5 \%$ ferric chloride $\left(\mathrm{FeCl}_{3}\right)$ 를 혼합한 후 실온에서 반응 시켜 spectrophotometer (Hitachi U-2900)로 $700 \mathrm{~nm}$ 에서 흡광도를 측정하였 다. 한편, $\mathrm{Cu}$-환원력 측정도 각 용매 추출물 $0.01,0.05,0.1$, 0.5 및 $1 \%$ 시료 용액에 $0.01 \mathrm{M} \mathrm{CuCl}_{2}, 7.5 \mathrm{mM}$ ethanolic neocuprorine solution, $1 \mathrm{M} \mathrm{NH}_{4} \mathrm{OAc}$ buffer를 혼합하여 상온에 서 반응시킨 후 $420 \mathrm{~nm}$ 에서 흡광도를 측정하였다. 이때 환원 력 비교를 위하여 천연 항산화제 ascorbic acid와 합성 항산화 제 $\mathrm{BHT}$ 를 각각 시료와 동일한 농도와 방법으로 흡광도를 측 정하였다.

\section{$\mathrm{Fe}^{+1} / \mathrm{ascorbate}$ 에 의해 유도된 항산화 활성 조사}

성장기의 정상 흰쥐 간 조직으로부터 microsome 분획을 조제 하였다. 간 microsome 분획을 이용한 항산화 활성은 Wong 등의 방법[31]에 따라 $50 \mathrm{mM}$ Tris-HCl buffer (pH 7.5), 간 microsome 분획 $(1 \mathrm{ml}$ 중 $1 \mathrm{mg}$ 의 단백질 함유), $0.1 \mathrm{mM}$ 
ascorbate 및 $5 \mathrm{mM} \mathrm{FeSO}_{4}$ 반응액을 잘 혼합한 후 $37^{\circ} \mathrm{C}$ 에서 1 시간 반응시켜 과산화를 유도시켰다. 이때 대조구는 시료를 첨가시키지 않고 동일한 방법으로 실시하였다. 반응액에 $3 \mathrm{M}$ trichloroacetic acid와 $2.5 \mathrm{~N} \mathrm{HCl}$ 의 혼합용액을 가하고 원심분 리 한 후 상등액에 $0.67 \% \mathrm{TBA}$ 를 넣고 가열하여 발색시켰다. 발색된 반응액은 $535 \mathrm{~nm}$ 에서 흡광도를 측정하였으며, 지질과 산화의 억제율은 대조구의 흡광도에 대한 저해율 $(\%)$ 로 비교 하였다.

\section{Thiocyanate에 의한 항산화 활성 측정}

Ohkawa의 방법[24]에 따라 먼저 linoleic acid로 유도된 과 산화 지질 용액에 $70 \%$ ethanol과 ammonium thiocyanate 용 액 $\left(0.3 \mathrm{~g} / \mathrm{ml}\right.$ in $\left.\mathrm{H}_{2} \mathrm{O}\right)$, ferrous chloride 용액 $(2.45 \mathrm{mg} / \mathrm{ml}$ in $3.5 \%$ hydrochloric acid)을 혼합한 후 정확히 3분 후에 $500 \mathrm{~nm}$ 에서 흡광도를 측정하였다. 이때 활성의 비교를 위하여 BHT 를 $0.05 \%$ 농도로 사용 하였다.

TBA (2-thiobarbituric acid)에 의한 항산화 활성 측정

Linoleic acid $(25 \mathrm{mg} / \mathrm{ml}$ in EtOH)를 기질로 하여 $0.2 \mathrm{M}$ phosphate buffer $\left(\mathrm{pH}\right.$ 7.0)와 각 시료 용액을 가하여 $40^{\circ} \mathrm{C}$ 에서 1 주일 동안 과산화 지질을 유도하였다[6]. 과산화 지질 측정은 반응액에 35\% trichloroacetic acid와 $0.75 \%$ aqueous $\mathrm{TBA}$ 를 혼합하고 가열처리 한 후 $70 \%$ trichloroacetic acid를 가한 다음 원심분리 하여 그 상등액을 $532 \mathrm{~nm}$ 에서 흡광도를 측정하였다.

\section{Tyrosinase 활성 측정}

Tyrosinase 활성은 Masamoto 등의 실험 방법[21]을 약간 변형하여 측정하였다. In vitro mushroom tyrosinase 활성 저 해 능력을 측정하기 위하여 $1.5 \mathrm{ml}$ plastic cuvette에 $2.5 \mathrm{mM}$ 3,4-dihydroxyphenylalanin (L-DOPA) $0.3 \mathrm{ml}$, 시료 추출물 $0.05 \mathrm{ml}$ 및 $0.1 \mathrm{M}$ phosphate buffer $\left(\mathrm{pH}\right.$ 6.8)을 혼합하여 $25^{\circ} \mathrm{C}$ 에서 먼저 반응시켰다. 여기에 1,380 units/ml mushroom tyrosinase (2,500 unit, Sigma Chemical Co., St. Louis, MO, USA) $0.05 \mathrm{ml}$ 를 넣은 후 $25^{\circ} \mathrm{C}$ 에서 2 분간 반응시키면서 475 $\mathrm{nm}$ 에서 흡광도를 측정하여 계산하였다. 대조구는 시료가 들 어있지 않는 시료 용해 용액을 사용하였고, 양성대조구는 tyrosinase 저해제로 알려진 $0.6 \mathrm{mM}$ kojic acid를 사용하였다. 이때 tyrosinase 활성 저해율(\%)은 다음의 공식에 의하여 산출 하였다

Tyrosinase 활성 저해율 $(\%)=100-[(\mathrm{A}-\mathrm{B}) / \mathrm{A}] \times 100$

$\mathrm{A}$ 는 시료가 들어있지 않은 반응액의 0.5-1분 사이의 흡광도 차이 $\mathrm{B}$ 는 시료가 들어있는 반응액의 0.5-1분 사이의 흡광도 차이

\section{혈전용해 효소 활성측정}

혈전용해 효소 활성은 fibrin plate 법[2]을 변형하여 lysed zone으로 측정하였다. Fibrin plate는 $0.06 \%$ fibrinogen (Sigma chem. Co., St. Louis, MO, USA)을 $0.2 \mathrm{M}$ borate buffer (pH 7.5)에 용해시킨 후 petri dish에 $10 \mathrm{ml}$ 씩 분주하고 thrombin (5,000 unit, Sigma chemical Co.) 40 unit를 균일하게 섞이도록 가하면서 균일한 두께의 fibrin clot를 형성시킨 후 실온에서 30 분간 방치한 후 사용하였다. 시료를 증류수에 $1 \%$ 농도로 용출시킨 후 여과(Whatman No. 2)하여 fibrin plate 상에 50 lㅣ씩 점적하여 $37^{\circ} \mathrm{C}$ 에서 3 시간 동안 반응시킨 후 생성된 투명 환 부위의 직경을 측정하였다. 직경은 서로 수직인 두 개의 지름을 측정하여 투명대의 면적을 구하여 unit/ml로 표시하 였다.

\section{통계처리}

실험으로부터 얻어진 결과치는 one-way ANOVA 검정에 의한 평균치와 표준오차 $(\operatorname{mean} \pm \mathrm{SE})$ 로 표시하였다[12].

\section{결과 및 고찰}

\section{추출물 수율}

동충하초의 수율은 전체적으로 수용성 추출물이 에탄올 추 출물과 메탄올 추출물보다 높았으며, 수용성 추출물중 $P$. japonica $(\mathrm{PJ})$ 가 $42.53 \%$ 로 가장 높고 C. militaris $(\mathrm{CM})$ 가 $7.63 \%$, C. militaris JLM0636 (CMa)는 19.76\% 순이었다(Table 1). Cha [9] 등은 동충하초의 균사체에서 수분 $3.72 \%$, 회분 7.03 , 조지방 $14.01 \%$, 조단백질 $20.54 \%$, 탄수화물 $54.70 \%$ 함유되어 있다 하 였고, 일반적으로 수용성 추출의 경우 수용성 전분, 수용성 섬유질, 수용성 펙틴질 및 단백질 등의 고분자물질이 다량 용 출되어 고농도 에탄올 사용 때보다 많은 양의 추출물을 얻을 수 있다고 했다[19]. 본 실험에서 동충하초의 수율이 수용성에 서 높게 나타난 것은 동충하초 균사체의 대부분이 수용성에 용출되기 쉬운 일부의 탄수화물과 조단백질로 이루어져 있기 때문이라 사료된다.

\section{총 페놀성 화합물 함량}

페놀성 화합물은 식물계에 널리 분포되어 있는 2 차 대사산 물로서 flavonoid, catechin, tannin 류로 크게 구분되며, 이들 물질들은 전자공여능이 있어 높은 항산화 작용을 나타내는 것으로 알려져 있다[23]. 페놀성 화합물 함량은 수용성 추출물 이 에탄올 추출물과 메탄올 추출물보다 높았으며 그 중 PJ가 $2.72 \%$ 로 $\mathrm{CM}$ 와 $\mathrm{CMa}$ 보다 더 많았다(Table 1). 수용성 추출물 이 지용성 추출물보다 더 많은 페놀성 화합물이 용출되었는 데, 이는 대부분의 동충하초의 유효성분이 수용성 추출물에서 많이 용출되었기 때문이라고 사료된다.

\section{플라보노이드 함량}

천연 항산화성 물질 중 대표적인 flavonoid는 혈압강하효 
Table 1. Extracted yield, concentrations of phenolic compounds and flavonoids in the water, ethanol, methanol extracts from Paecilomyces japonica (PJ), Cordyceps militaris (CM) and Cordyceps militaris JLM0636 (CMa)

\begin{tabular}{|c|c|c|c|c|c|c|c|c|c|}
\hline & \multicolumn{3}{|c|}{ Extracted yield (\%) } & \multirow{2}{*}{$\begin{array}{c}\text { Total phenolic } \\
\text { PJ }\end{array}$} & \multicolumn{2}{|c|}{ compounds concentrations (\%) } & \multicolumn{3}{|c|}{ Flavonoids concentrations (\%) } \\
\hline & PJ & $\mathrm{CM}$ & $\mathrm{CMa}$ & & $\mathrm{CM}$ & $\mathrm{CMa}$ & PJ & $\mathrm{CM}$ & $\mathrm{CMa}$ \\
\hline Water & 42.53 & 7.63 & 19.76 & $2.72 \pm 0.24^{\mathrm{a}}$ & $0.48 \pm 0.07^{\text {bc }}$ & $1.43 \pm 0.09^{\mathrm{d}}$ & $1.73 \pm 0.61^{\mathrm{a}}$ & $0.28 \pm 0.04^{b}$ & $0.99 \pm 0.16^{b}$ \\
\hline Ethanol & 14.11 & 6.12 & 11.68 & $0.82 \pm 0.05^{b}$ & $0.34 \pm 0.04^{\mathrm{c}}$ & $0.62 \pm 0.02^{\mathrm{bc}}$ & $0.46 \pm 0.08^{b}$ & $0.26 \pm 0.02^{b}$ & $0.97 \pm 0.33^{b}$ \\
\hline Methanol & 10.27 & 5.27 & 7.97 & $0.41 \pm 0.03^{\mathrm{c}}$ & $0.41 \pm 0.16^{\mathrm{c}}$ & $0.45 \pm 0.05^{\mathrm{c}}$ & $0.20 \pm 0.03^{b}$ & $0.27 \pm 0.16^{\mathrm{b}}$ & $0.34 \pm 0.03^{b}$ \\
\hline
\end{tabular}

Values are mean $\pm \mathrm{SE}, \mathrm{n}=3$.

Table 2. Fatty acid compositions of Paecilomyces japonica (PJ), Cordyceps militaris (CM) and Cordyceps militaris JLM0636 (CMa) (\% for area of total fatty acids)

\begin{tabular}{cccccccccccc}
\hline Fatty acid & $\begin{array}{c}\text { Myristic } \\
\text { acid } \\
(14: 0)\end{array}$ & $\begin{array}{c}\text { Palmitic } \\
\text { acid } \\
(16: 0)\end{array}$ & $\begin{array}{c}\text { Palmitoleic } \\
\text { acid } \\
(16: 1, \mathrm{n}=9)\end{array}$ & $\begin{array}{c}\text { Stearic } \\
\text { acid } \\
(18: 0)\end{array}$ & $\begin{array}{c}\text { Oleic } \\
\text { acid } \\
(18: 1, \mathrm{n}=9)\end{array}$ & $\begin{array}{c}\text { Linoleic } \\
\text { acid }\end{array}$ & $\begin{array}{c}\text { Linolenic } \\
\text { acid }\end{array}$ & $\begin{array}{c}\text { Arachidic } \\
\text { acid } \\
(28: 0)\end{array}$ & SFA & MUFA & PUFA \\
\hline PJ & 0.06 & 29.94 & 0.73 & 4.57 & 27.39 & 11.70 & 25.23 & 0.38 & 34.95 & 28.12 & 36.93 \\
CM & 2.45 & 33.09 & 0.12 & 19.22 & 26.31 & 5.12 & 12.18 & 1.51 & 56.27 & 26.43 & 17.30 \\
CMa & 3.73 & 36.58 & 3.05 & 13.41 & 39.22 & 0.93 & 1.99 & 1.08 & 54.80 & 42.28 & 2.92 \\
\hline
\end{tabular}

SFA: saturated fatty acid

MUFA: monounsaturated fatty acid

PUFA: polyunsaturated fatty acid

과, 당뇨병과 galactosemia의 억제효과, 적혈구 세포 응고의 감소효과, rheumatic fever의 예방효과, 항균 활성, 항산화 효 과, 항염증 작용, 콜레스테롤 저하작용, 지방간 억제 작용 등이 보고되어 있으며, 여러 종양 세포의 성장 및 분화를 저해시키 는 효과도 다수 보고되어 있다[8]. 이러한 flavonoid는 담황색 또는 노란색을 띠고 있는 색소화합물로서 자연에서 유리상태 로 존재하기도 하나 대개는 rhamnose, glucose, rutinose 등의 당과 결합한 배당체로 존재하는 것으로 알려져 있다[3]. 플라 보노이드 함량은 페놀성 화합물의 결과와 비슷한 양상으로 수용성 추출물이 에탄올 추출물과 메탄올 추출물 보다 높았 다. $\mathrm{PJ}$ 가 $1.73 \%$ 로 가장 많았으며 $\mathrm{CMa}$ 와 $\mathrm{CM}$ 는 $0.99 \%, 0.28 \%$ 였다(Table 1). 대부분의 식물체에서 폴리페놀 함량이 플라보 노이드보다 많이 함유 되어 있으면서 대체로 폴리페놀 함량이 많은 식물이 플라보노이드의 함량도 많이 함유하고 있는데, 동충하초도 폴리페놀 함량이 높은 것은 플라보노이드 함량이 높은 것으로 보아 이들 결과와 일치하였다[18].

\section{지방산 함량}

$\mathrm{PJ}, \mathrm{CM}$ 와 $\mathrm{CMa}$ 의 주요 지방산 성분으로 palmitic acid, oleic acid, stearic acid 가 많이 함유 되어 있었다(Table 2). PJ에 포화 지방산은 $34.95 \%$ 와 불포화지방산은 $65.02 \%$ 를 차지하고 있고 그 중 palmitic acid가 $30.3 \%$ 를 함유하고 있었다. CM는 포화 지방산과 불포화 지방산이 $56.27 \%, 43.73 \%$ 이며 그 중 $\mathrm{li}-$ noleic acid가 $44.6 \%$ 를 함유하고 있었다. 또한 $\mathrm{CMa}$ 도 포화지 방산 $54.80 \%$ 와 불포화지방산 $45.2 \%$ 로 포화지방산의 비율이 많았지만 그 중 불포화 지방산 $\mathrm{n}=9$ 계열의 oleic acid 가 $39.22 \%$ 를 차지하고 있었다. Cordycepin 고함유 $\mathrm{CMa}$ 는 불포
화 지방산의 비율이 $\mathrm{CM}$ 보다 높은 것을 확인 할 수 있었는데 그 중 $\mathrm{n}=9$ 계열의 palmitoleic acid의 비율이 $0.12 \%$ 에서 $3.05 \%$ 로 약간 증가 한 것을 알 수 있었고, $\mathrm{n}=9$ 계열의 oleic acid의 비율도 $26.31 \%$ 에서 39.22 로 증가했다. 이 결과로 동충하초에 따라 지방산 조성 비율이 많이 달라질 수 있다는 것을 알 수 있었다. Yun [32]은 동충하초 자실체가 성장하면서 지방산을 흡수 이용해 조성에 많은 차이를 줄 수가 있다고 보고 했으며 이는 본 실험과 일치하였다.

\section{미네랄 함량}

$\mathrm{PJ}, \mathrm{CM}$ 와 $\mathrm{CMa}$ 의 미네랄 함량을 측정한 결과는 Table 3 와 같다. 미네랄 성분 조성 비율을 보면 전체적으로 $\mathrm{PJ}, \mathrm{CM}$ 와 $\mathrm{CMa}$ 의 $\mathrm{K}$ 이 각각 $1483.33 \mathrm{mg} / 100 \mathrm{~g}, 236.00 \mathrm{mg} / 100 \mathrm{~g}$, $1014.67 \mathrm{mg} / 100 \mathrm{~g}$ 으로 PJ에 가장 많이 함유되어 있었으며, 다음 $\mathrm{Mg}$ 도 $369.33 \mathrm{mg} / 100 \mathrm{~g}, 176.00 \mathrm{mg} / 100 \mathrm{~g}, 315.33$ $\mathrm{mg} / 100 \mathrm{~g}$ 으로 PJ에서 가장 많이 함유되어 있었다. 나머지 Ca, $\mathrm{Na}, \mathrm{Fe}, \mathrm{Zn}, \mathrm{Mg}, \mathrm{Cu}$ 는 소량 함유되어 있었다. 이 실험은 $\mathrm{Cha}$ 등[9]의 동충하초 추출물과 균사체의 미네랄 함량에 대한 결과 와도 비슷하게 나타났다.

\section{$\mathrm{DPPH}$ free radical에 의한 전자공여 활성}

$\mathrm{DPPH}$ 는 비교적 안정한 free radical로써 항산화 활성을 간 단히 측정할 수 있는 동시에 실제 항산화 활성과도 연관성이 매우 높기 때문에 많이 이용되고 있다[7]. 본 연구 결과에서 $\mathrm{PJ}, \mathrm{CM}$ 와 $\mathrm{CMa}$ 의 용매별 추출물의 $\mathrm{DPPH}$ 항산화 활성은 대부 분의 식물 추출물에서 폴리페놀 화합물 또는 플라보노이드 함량이 높을수록 항산화 활성이 높다는 결과와 일치하였고 
Table 3. Mineral contents in Paecilomyces japonica (PJ), Cordyceps militaris (CM) and Cordyceps militaris JLM0636 (CMa)

\begin{tabular}{lccc}
\hline & \multicolumn{3}{c}{ Mineral concentrations (mg/100 g dry wt) } \\
\cline { 2 - 4 } & PJ & CM & CMa \\
\hline Potassium & $1483.33 \pm 24.39^{\mathrm{a}}$ & $236.00 \pm 2.89^{\mathrm{b}}$ & $1014.67 \pm 36.17^{\mathrm{c}}$ \\
Magnesium & $369.33 \pm 4.26^{\mathrm{a}}$ & $176.00 \pm 0.58^{\mathrm{b}}$ & $315.33 \pm 1.20^{\mathrm{c}}$ \\
Calcium & $26.92 \pm 0.09^{\mathrm{a}}$ & $23.41 \pm 0.03^{\mathrm{b}}$ & $141.67 \pm 0.29^{\mathrm{c}}$ \\
Sodium & $52.97 \pm 0.75^{\mathrm{a}}$ & $13.37 \pm 0.03^{\mathrm{b}}$ & $14.73 \pm 0.39^{\mathrm{b}}$ \\
Iron & $8.93 \pm 0.12^{\mathrm{a}}$ & $5.44 \pm 0.14^{\mathrm{b}}$ & $3.46 \pm 0.08^{\mathrm{c}}$ \\
Zinc & $1.61 \pm 0.02^{\mathrm{a}}$ & $4.37 \pm 0.11^{\mathrm{b}}$ & $9.94 \pm 0.01^{\mathrm{c}}$ \\
Manganese & $1.76 \pm 0.03^{\mathrm{a}}$ & $4.13 \pm 0.01^{\mathrm{b}}$ & $3.53 \pm 0.03^{\mathrm{c}}$ \\
\hline
\end{tabular}

Values are mean $\pm S E, n=3$.

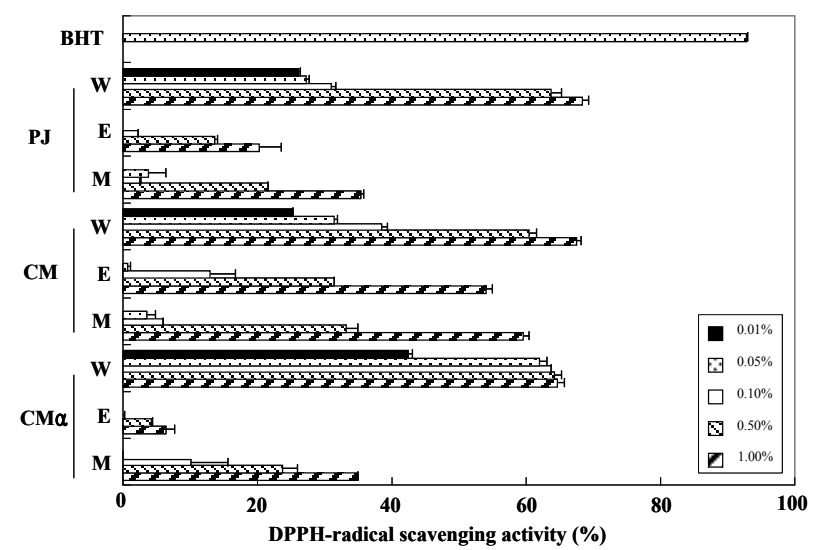

Fig. 1. DPPH radical scavenging activities of water (W), ethanol (E), and methanol (M) extracts from Paecilomyces japonica (PJ), Cordyceps militaris (CM) and Cordyceps militaris JLM0636 (CMa). BHT: butylated hydroxytoluene $(0.05 \%)$; Values are mean \pm SE, $n=3$. Values with different letters are significantly different at $p<0.05$.

[18], 시료의 처리 농도 증가와 함께 활성도 증가되는 경향을 보였다(Fig. 1). 또한 항산화 활성은 추출 용매의 차이에 의해 서도 영향을 받는 것으로 나타나 전체적으로 수용성 추출물이 가장 높은 항산화 활성을 나타냈고 메탄올 추출물, 에탄올 추 출물 순으로 나타난 것을 알 수 있다. 시료의 $1 \%$ 농도에서는 $\mathrm{PJ}$ 의 수용성 추출물이 $68.34 \%$ 로 $\mathrm{CM}$ 와 $\mathrm{CMa}$ 의 $67.42 \%$, $64.58 \%$ 보다 약간 높았다. 그러나 시료의 $0.05 \%$ 의 농도에서는 $\mathrm{CMa}$ 가 $61.97 \%$ 로 나타났으며 $1 \%$ 농도와 많은 차이가 나타나 지 않은 것으로 보아 낮은 농도로 높은 항산화 활성이 나타남 을 알 수 있었다. 이 때 대조구로 사용된 시판 합성 항산화제인 BHT $0.05 \%$ 처리에 의해서는 $92.76 \%$ 로 항산화 활성이 높았다. 이상의 결과에서 높은 농도에서는 $\mathrm{PJ}$ 의 항산화 활성이 높았지 만 시료의 농도가 낮아짐에 따라 시료농도의 영향을 많이 받 지 않는 $\mathrm{CMa}$ 가 높은 항산화 활성을 나타났다.

\section{환원력 효과}

$\mathrm{Fe}$ 또는 $\mathrm{Cu}$ 환원력에 의한 항산화 반응은 수소 원자를 제공 하는 유리 라디칼의 연쇄 반응이며, 또한 과산화 반응에서 일
정한 전구물질과 반응하여 과산화 물질의 형성을 방해하는데, 플라보노이드 화합물은 이 안정된 생성물로 이들을 전환시키 기 위하여 유리기와 반응하거나 전자를 공여함으로서 환원과 같은 유사한 형태에서 반응하고 유리 라디칼 연쇄반응을 종료 하는 것으로 알려져 있다[30]. 본 연구결과에서 $\mathrm{Fe}$ 환원력은 $\mathrm{PJ}$ 의 수용성 추출물 $1 \%$ 에서 1.8 로 $\mathrm{CM}$ 와 $\mathrm{CMa}$ 의 $1.69,1.68$ 보다 높게 나왔으며, 메탄올 추출물 $1 \%$ 에서는 $\mathrm{CMa}$ 가 0.97 로 $\mathrm{CM}$ 의 0.95 와 PJ의 0.65 보다 더 높았다(Table 4). 그리고 에탄올 추출 물 $1 \%$ 에서도 $\mathrm{CMa}$ 가 0.79 로 $\mathrm{CM}$ 의 0.76 와 $\mathrm{PJ}$ 의 0.57 보다 더 높았다. 수용성 추출물에서 PJ가 가장 높은 환원력을 나타났는 데 이는 추출물 중에 함유된 폴리페놀 화합물 및 플라보노이 드 함량과 밀접한 관계를 보이는 것으로 사료된다. 하지만 $\mathrm{Cu}$ 환원력의 경우에는 조금 다른 경향을 보였는데 전체적으로 메탄올 추출물과 에탄올 추출물이 수용성 추출물보다 조금 더 높은 환원력을 보였다(Table 4). 한편, 모든 용매에서 PJ의 환원력이 $\mathrm{CM}$ 와 $\mathrm{CMa}$ 보다 더 높은 환원력을 확인하였다.

\section{간장 microsome의 지질 과산화 억제활성}

지질 과산화 반응은 여러 가지 독성 화학물이나 약물 또는 당뇨병 등 생체 이상에 의해 간세포에 중대한 손상을 입히는 것으로 알려져 있어[28], 생체 내에서 지질 과산화물의 제어는 매우 중요하다. 동물 체내에서 생체막 지질의 과산화물 생성 정도를 나타내는 TBARS 함량은 각 조직 세포의 microsome에 $\mathrm{Fe}^{++} /$ascorbate을 첨가하여 비효소적으로 유도하는데[31], PJ, $\mathrm{CM}$ 와 $\mathrm{CMa}$ 의 용매추출물에서 농도 의존적으로 높은 지질 과 산화 억제활성을 나타내었다(Fig. 2). 전체적으로 모든 용매추 출물에서 높은 활성을 나타났는데 그 중 $\mathrm{CMa}$ 의 에탄올 추출 물 $1 \%$ 가 $86.76 \%$ 로 높은 지질 과산화 억제활성이 나타났다. 이 때 대조구로 사용된 시판 합성 항산화제인 BHT $0.05 \%$ 가 $88.24 \%$ 의 활성을 나타내었다.

\section{불포화 지방산 linoleic acid 산화 실험계를 이용한 항산화} 활성

불포화 지방산인 linoleic acid를 이용한 thiocyanate 방법으 로 $\mathrm{PJ}, \mathrm{CM}$ 와 $\mathrm{CMa}$ 의 용매별 추출물의 항산화 활성을 측정한 
Table 4. Reducing power of water (W), ethanol (E), and methanol (M) extracts from Paecilomyces japonica (PJ), Cordyceps militaris (CM) and Cordyceps militaris JLM0636 (CMa)

\begin{tabular}{|c|c|c|c|c|c|c|c|}
\hline \multirow{2}{*}{ Composition } & \multirow{2}{*}{ Conc. $(\%)$} & \multicolumn{3}{|c|}{ Fe-Reducing power } & \multicolumn{3}{|c|}{ Cu-Reducing power } \\
\hline & & PJ & $\mathrm{CM}$ & $\mathrm{CMa}$ & $\mathrm{PJ}$ & $\mathrm{CM}$ & $\mathrm{CMa}$ \\
\hline \multirow{5}{*}{ BHT } & 0.01 & & $0.46 \pm 0.04$ & & & $0.78 \pm 0.01$ & \\
\hline & 0.05 & & $0.93 \pm 0.01$ & & & $1.74 \pm 0.08$ & \\
\hline & 0.10 & & $1.00 \pm 0.00$ & & & $2.38 \pm 0.02$ & \\
\hline & 0.50 & & $1.08 \pm 0.04$ & & & $3.51 \pm 0.10$ & \\
\hline & 1.00 & & $1.11 \pm 0.04$ & & & $3.61 \pm 0.00$ & \\
\hline \multirow{5}{*}{ AA } & 0.01 & & $0.92 \pm 0.03$ & & & $0.57 \pm 0.01$ & \\
\hline & 0.05 & & $0.99 \pm 0.00$ & & & $1.35 \pm 0.11$ & \\
\hline & 0.10 & & $1.13 \pm 0.01$ & & & $1.54 \pm 0.02$ & \\
\hline & 0.50 & & $1.16 \pm 0.02$ & & & $1.91 \pm 0.01$ & \\
\hline & 1.00 & & $1.16 \pm 0.07$ & & & $2.07 \pm 0.00$ & \\
\hline \multirow{5}{*}{ Water } & 0.01 & $0.06 \pm 0.00$ & $0.05 \pm 0.00$ & $0.04 \pm 0.00$ & $0.04 \pm 0.01$ & $0.04 \pm 0.01$ & $0.04 \pm 0.00$ \\
\hline & 0.05 & $0.18 \pm 0.01$ & $0.13 \pm 0.00$ & $0.17 \pm 0.00$ & $0.09 \pm 0.00$ & $0.11 \pm 0.00$ & $0.12 \pm 0.00$ \\
\hline & 0.10 & $0.22 \pm 0.03$ & $0.20 \pm 0.00$ & $0.24 \pm 0.00$ & $0.24 \pm 0.00$ & $0.17 \pm 0.00$ & $0.20 \pm 0.00$ \\
\hline & 0.50 & $1.02 \pm 0.01$ & $0.92 \pm 0.00$ & $0.98 \pm 0.02$ & $1.48 \pm 0.02$ & $0.84 \pm 0.00$ & $0.75 \pm 0.02$ \\
\hline & 1.00 & $1.80 \pm 0.09$ & $1.69 \pm 0.02$ & $1.68 \pm 0.02$ & $2.12 \pm 0.02$ & $1.46 \pm 0.01$ & $1.13 \pm 0.02$ \\
\hline \multirow{5}{*}{ Ethanol } & 0.01 & $0.09 \pm 0.01$ & $0.07 \pm 0.01$ & $0.10 \pm 0.01$ & $0.04 \pm 0.00$ & $0.04 \pm 0.00$ & $0.06 \pm 0.00$ \\
\hline & 0.05 & $0.10 \pm 0.00$ & $0.12 \pm 0.01$ & $0.11 \pm 0.00$ & $0.25 \pm 0.01$ & $0.19 \pm 0.01$ & $0.21 \pm 0.01$ \\
\hline & 0.10 & $0.13 \pm 0.00$ & $0.16 \pm 0.00$ & $0.16 \pm 0.00$ & $0.59 \pm 0.01$ & $0.25 \pm 0.01$ & $0.40 \pm 0.01$ \\
\hline & 0.50 & $0.34 \pm 0.02$ & $0.50 \pm 0.02$ & $0.51 \pm 0.00$ & $2.08 \pm 0.05$ & $1.22 \pm 0.04$ & $1.46 \pm 0.02$ \\
\hline & 1.00 & $0.57 \pm 0.01$ & $0.76 \pm 0.02$ & $0.79 \pm 0.03$ & $2.53 \pm 0.02$ & $2.28 \pm 0.03$ & $2.3 \pm 0.01$ \\
\hline \multirow{5}{*}{ Methanol } & 0.01 & $0.04 \pm 0.00$ & $0.08 \pm 0.01$ & $0.06 \pm 0.00$ & $0.13 \pm 0.01$ & $0.21 \pm 0.03$ & $0.11 \pm 0.00$ \\
\hline & 0.05 & $0.07 \pm 0.00$ & $0.12 \pm 0.00$ & $0.13 \pm 0.00$ & $0.48 \pm 0.10$ & $0.27 \pm 0.01$ & $0.23 \pm 0.00$ \\
\hline & 0.10 & $0.13 \pm 0.00$ & $0.23 \pm 0.01$ & $0.23 \pm 0.02$ & $0.60 \pm 0.05$ & $0.41 \pm 0.01$ & $0.39 \pm 0.00$ \\
\hline & 0.50 & $0.40 \pm 0.00$ & $0.65 \pm 0.01$ & $0.72 \pm 0.00$ & $1.88 \pm 0.00$ & $1.19 \pm 0.04$ & $1.61 \pm 0.01$ \\
\hline & 1.00 & $0.65 \pm 0.02$ & $0.95 \pm 0.00$ & $0.97 \pm 0.01$ & $2.71 \pm 0.08$ & $2.35 \pm 0.11$ & $2.37 \pm 0.10$ \\
\hline
\end{tabular}

BHT: butylated hydroxytoluene; AA: ascorbic acid; Values are mean \pm SE, $n=3$.

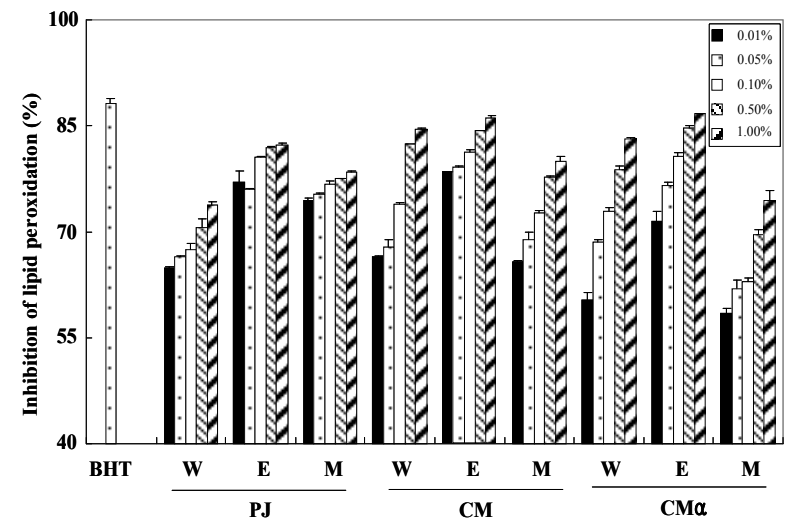

Fig. 2. Antioxidant activities of water (W), ethanol (E), and methanol (M) extracts from Paecilomyces japonica (PJ), Cordyceps militaris (CM) and Cordyceps militaris JLM0636 (CMa) on lipid peroxidation using rat liver homogenate as measured by TBARS method. BHT: butylated hydroxytoluene $(0.05 \%)$; Values are mean $\pm S E, n=3$. Values with different letters are significantly different at $p<0.05$.
결과는 Fig. 3과 같다. 반응 7일째에 대조구에 대한 상대 활성 으로 나타낸 결과는 농도 의존적으로 농도가 높을수록 높은 항산화 활성을 보였으며 수용성 추출물이 에탄올과 메탄올 추출물 보다는 산화 저해율이 높게 나타났다. $\mathrm{PJ}$ 는 $1 \%$ 처리했 을 때 수용성 추출물이 약 $64.29 \%$ 로 가장 높은 저해율을 보였 고 메탄올 $56.6 \%$, 에탄올 $53.77 \%$ 로 나타났다. $\mathrm{CMa}$ 는 $1 \%$ 처리 했을 때 수용성 추출물이 $64.15 \%$ 로 나타났고 메탄올 $61.35 \%$, 에탄올 $59.66 \%$ 로 나타났다. 또한 CM는 $1 \%$ 처리했을 때 수용 성 추출물이 $55.78 \%$ 로 나타났고 메탄올 $58.23 \%$, 에탄올 $53.9 \%$ 로 나타났다. 이들에 비해 대조구로 사용된 시판 합성 항산화 제인 $\mathrm{BHT}$ 는 $83.69 \%$ 의 높은 항산화 활성을 보였다.

불포화 지방산인 linoleic acid를 이용한 TBA법으로 $\mathrm{PJ}, \mathrm{CM}$ 와 $\mathrm{CMa}$ 의 용매별 추출물의 항산화 활성을 측정한 결과는 Fig. 4 와 같다. TBA법으로 진행한 결과도 thiocyanate법과 비슷하 게 나타났는데 전체적으로 수용성 추출물의 산화 저해율이 에탄올과 메탄올보다 높았으며 또한 농도 의존적으로 농도가 높을수록 저해율이 높았다. PJ의 수용성 추출물 $1 \%$ 처리시 


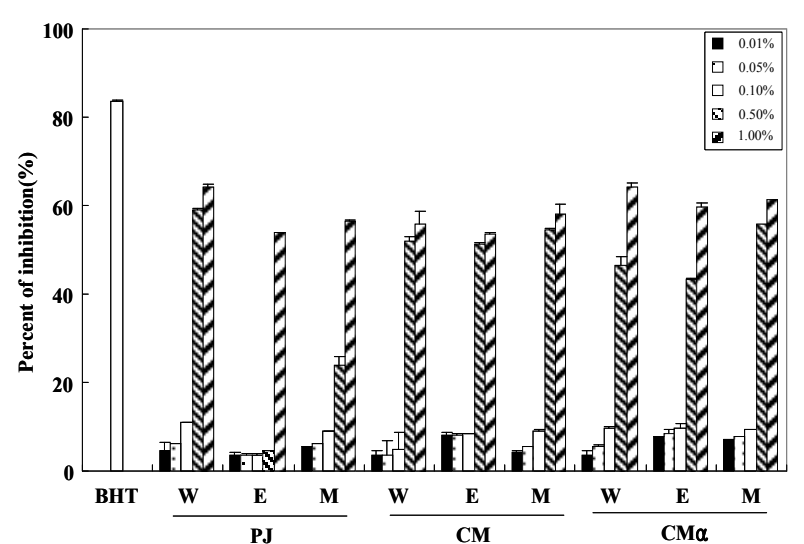

Fig. 3. Antioxidant activities of water (W), ethanol (E), and methanol (M) extracts from Paecilomyces japonica (PJ), Cordyceps militaris (CM) and Cordyceps militaris JLM0636 $(\mathrm{CMa})$ on linoleic acid oxidation as measured by the ferric thiocyanate method. BHT: butylated hydroxytoluene $(0.05 \%)$; Values are mean $\pm S E, n=3$. Values with different letters are significantly different at $p<0.05$.

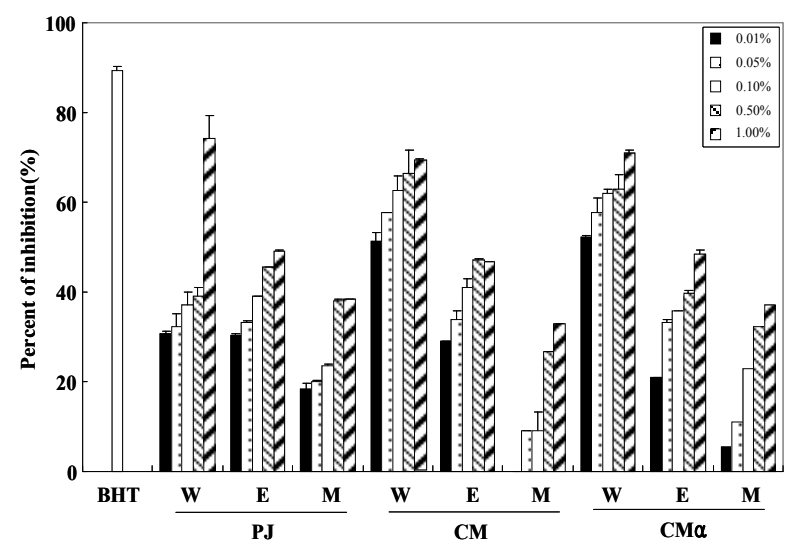

Fig. 4. Antioxidant activities of water (W), ethanol (E), and methanol (M) extracts from Paecilomyces japonica (PJ), Cordyceps militaris (CM) and Cordyceps militaris JLM 0636 $(\mathrm{CMa})$ on lipid peroxidation as measured by ferric TBA method. BHT: butylated hydroxytoluene $(0.05 \%)$; Values are mean $\pm S E, n=3$. Values with different letters are significantly different at $p \ll 0.05$.

$74.3 \%$ 로 가장 높았으며 다음은 $\mathrm{CMa}$ 가 $70.85 \%$ 로 $\mathrm{CM}$ 의 $69.88 \%$ 보다 높은 저해율을 보였다. 이때 대조구로 사용된 시 판 합성 항산화제인 $\mathrm{BHT}$ 는 약 $89.44 \%$ 의 높은 항산화 활성을 보였다.

\section{Tyrosinase 활성}

멜라닌(melanin)은 자연계에 널리 분포하는 페놀류의 생물 고분자 물질로 표피층의 melanocyte라는 색소세포 내의 melanosome에서 합성되는데, tyrosine을 시발 물질로 하여 tyrosinase 효소에 의해 DOPA (3,4-dihydroxy-phenylalanine)

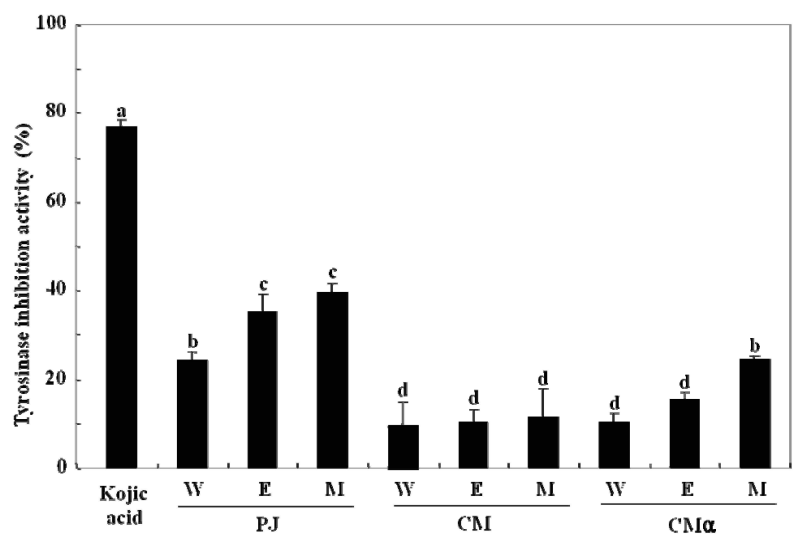

Fig. 5. Tyrosinase inhibition activities of water (W), ethanol (E), and methanol $(\mathrm{M})$ extracts from Paecilomyces japonica (PJ), Cordyceps militaris (CM) and Cordyceps militaris JLM $0636(\mathrm{CMa})$. Values are mean $\pm S E, n=3$. Values with different letters are significantly different at $p<0.05$.

또는 DOPA 퀴논으로 산화 및 중합 반응에 의해 멜라닌이 만 들어 진다[22]. 이때 생성되는 멜라닌이 자외선과 같은 피부자 극에 대해 저항력을 높여주지만 사람의 기미와 주근깨 등 피 부에 생기는 색소침착은 과도한 멜라닌색소 생성에 기인한다. 이때 피부 미백효과를 측정하는 하나의 지표로 tyrosinase 활 성을 측정하고 이를 효과적으로 저해하는 생리활성물질을 탐 색하는 것은 화장품등 여러 산업에서 매우 중요한 부분이다. 본 연구결과에서 모든 시료의 처리 농도는 $1 \%$ 였고, 대조구로 사용된 kojic acid는 $76.81 \%$ 로 높은 tyrosinase 저해활성을 나 타내었다. PJ의 tyrosinase 저해 활성이 $\mathrm{CM}$ 와 $\mathrm{CMa}$ 보다 높았 으며 그 중 메탄올 추출물은 $39.6 \%$ 로 에탄올 추출물 $35.41 \%$ 와 수용성 추출물 $24.12 \%$ 보다 높았다(Fig. 5). Park [21]은 뽕잎 추출물을 이용한 동충하초 $(P$. japonica) 균사체 배양액의 tyrosinase 저해율이 시료의 처리농도가 $20 \%$ 첨가시 $50 \%$ 저해 율과 $50 \%$ 첨가시 $100 \%$ 저해효과를 보고하였다. 다음으로 $\mathrm{CM}$ $\mathrm{a}$ 가 $\mathrm{CM}$ 보다 저해활성이 높았으며 $\mathrm{CMa}$ 의 메탄올 추출물은 $24.54 \%, \mathrm{CM}$ 의 메탄올 추출물은 $11.42 \%$ 로 나타났다. 이는 멜 라노마 세포 증식과 멜라닌 생합성을 억제시키는 대표적인 화합물 중에 페놀성 화합물, flavonoid, albutin, glycolic acid, kojic acid, pentadecenoic acid, ferulic acid, isoflavonoids 등 이 제시되고 있는데[17], 이러한 화합물이 동충하초 추출물에 서 추출되었기 때문이라 사료된다.

\section{혈전용해 효소 활성}

혈전증(thrombosis)은 다양한 요인에 의한 혈전의 과다생 성으로 인해 혈액순환이 비정상적인 상태를 말하는데, 이로 인해 혈행속도 감소, 혈액점도 이상 및 조직 기관의 손상 등의 문제점을 야기하며[5], 특히 심혈관 및 뇌혈관 이상의 경우 생 명의 위협을 받기도 한다. 그러나 이 때 혈전 용해 효소가 활성 화되면 혈전 생성이 억제되어 각종 순환기계 질병을 예방하는 


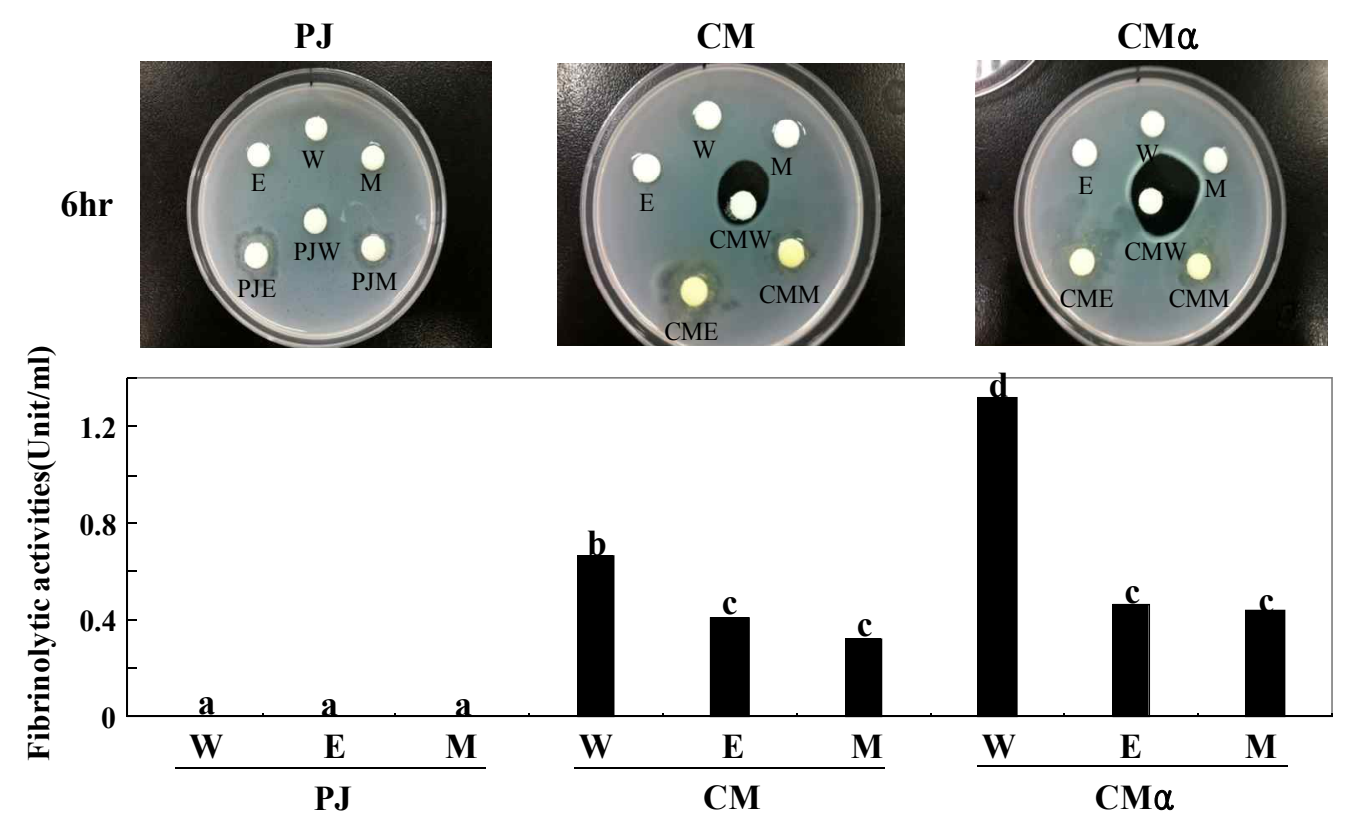

Fig. 6. Fibrinolytic activities of water (W), ethanol (E), and methanol (M) extracts from Paecilomyces japonica (PJ), Cordyceps militaris $(\mathrm{CM})$ and Cordyceps militaris JLM $0636(\mathrm{CMa})$. Values are mean $\pm \mathrm{SE}, \mathrm{n}=3$.

데 효과가 있다고 알려져 있어[25], 혈전 용해 효소에 대한 연 구가 활발히 진행중이다. 본 연구 결과에서 PJ의 뚜렷한 혈전 용해 활성은 없었으며 그 중 에탄올 추출물과 메탄올 추출물 은 응집력이 없어 시료 분주 후 바로 퍼지는 특징을 나타냈다 (Fig. 6). 나머지 $\mathrm{CM}$ 과 $\mathrm{CMa}$ 의 수용성 추출물에서 $\mathrm{CMa}$ 가 1.32 unit $/ \mathrm{ml}$ 로 $\mathrm{CM}$ 의 $0.6 \mathrm{unit} / \mathrm{ml}$ 보다 약 2 배 이상 높은 혈전용해 효소 활성을 보였다. 또한 에탄올 추출물과 메탄올 추출물에 서도 $\mathrm{CM}$ 보다 $\mathrm{CM}$ 가 조금 더 높은 활성을 보였다. 이 결과로 $\mathrm{CMa}$ 가 혈전 용해 효소제 개발에 도움이 될 수 있다 사료되며 더 심화된 연구가 필요하다.

이상의 연구에서 총 폴리페놀 화합물 함량, 플라보노이드 함량은 $\mathrm{PJ}$ 가 높았지만 $\mathrm{CM} a$ 가 $\mathrm{CM}$ 보다 높은 것을 확인했다. $\mathrm{DPPH}$ free radical scavenging 활성, $\mathrm{Fe} / \mathrm{Cu}$ reducing power, 간장 microsome의 지질 과산화 억제활성과 thiocyanate법 및 $\mathrm{TBA}$ 법에 의한 지질과산화 정도를 밨을때도 비교적 $\mathrm{PJ}$ 가 좋았 다. 전체적으로 국내에서 개발된 품종인 PJ의 항산화 능력이 높았지만 $\mathrm{CM}$ 보다는 $\mathrm{CMa}$ 의 항산화 능력이 더 뛰어났고, 특히 혈전용해 효소 활성에서 $\mathrm{CMa}$ 의 혈전분해능이 높은 것을 확인 했다. 이상의 실험결과를 바탕으로 $\mathrm{CMa}$ 는 $\mathrm{CM}$ 보다 비교적 높은 항산화활성을 나타냈고 높은 혈전 분해능이 있는 것을 확인하였다. 향후 산업적으로 이용가능성이 있을것으로 사료 되어 진다.

\section{감사의 글}

본 연구는 농림수산식품부 Medi-Farm 산업화 연구사업단 연구비(610003032SB120) 지원에 의해 이루어졌습니다.

\section{References}

1. A.O.A.C. 1975. Official methods of analysis. 12th eds., Association of official analytical chemists. Washington, D.C., U.S.A.

2. Astrup, T. and Mullertz, S. 1952. The fibrin plate method for estimating fibrinolytic activity. Arch Biochem Biophys 40, 346-351.

3. Bate-Smith, E. C. 1954. Flavonoid compounds in foods. In Advanced Food Res 5, 216.

4. Blois, M. S. 1958. Antioxidant determination by the use of a stable free radical. Nature 26, 1199-1204.

5. Butenas, S. and Mullertz, S. 2002. Blood coagulation. Biochemistry (Moscow) 67, 3-12.

6. Cha, J. Y. and Cho, Y. S. 1999. Effect of potato polyphenolics on lipid peroxidation in rats. J Korean Soc Food Sci Nutr 28, 1131-1136.

7. Cha, J. Y., Kim, H. J., Chung, C. H. and Cho, Y. S. 1999. Antioxidative activities and contents of polyphenolic compound of Cudrania tricuspidata. J Korean Soc Food Sci Nutr 28, 1310-1315.

8. Cha, J. Y., Cho, Y. S., Kim, I., Anno, T., Rahman, S. M. and Yanagita, T. 2001. Effect of hesperetin, a citrus flavonoid, on the liver triacylglycerol content and phosphatidate phosphohydrolase activity in orotic acid-fed rats. Plant Foods Human Nutr 56, 349-358.

9. Cha, W. S., Cho, B. S. and Park, S. Y. 2004. A study on the composition of Cordyceps militaris extract and mycelium. $J$ Life Sci 14,727-731.

10. Cho, H. J., Cho, J. Y., Rhee, M. H., Kim, H. S., Lee, H. S. and Park, H. J. 2007. Inhibitory effects of cordycepin (3'-deoxyadenosine), a component of Cordyceps militaris, on hu- 
man platelet aggregation induced by thapsigargin. $J$ Microbiol Biotechnol 17, 1134-1138.

11. Devasagayam, T. P., Tilak, J. C., Boloor, K. K., Sane, K. S., Sane, S. S. and Lele, R. D. 2004. Free radicals and antioxidants in human health: current status and future prospects. J Assoc Physicians India 52, 794-804.

12. Duncan, D. B. 1959. Multiple range and multiple $F$ test. Biometrics 1, 1-42.

13. Garces, R. and Mancha, M. 1993. One-step lipid extraction and fatty acid methyl esters preparation from fresh plant tissues. Anal Biochem 211, 139-143.

14. Guo, P., Kai, Q., Gao, J., Lian, Z. Q., Wu, C. M., Wu, C. A. and Zhu, H. B. 2010. Cordycepin prevents hyperlipidemia in hamsters fed a high-fat diet via activation of AMP-activated protein kinase. J Pharmacol Sci 113, 395-403.

15. Jia, Z., Tang, M. and Wu, J. 1999. The determination of flavonoid contents in mulberry and thier scavenging effects on superoxide radicals. Food Chem 64, 555-559.

16. Johnson, J. E., Harma, R. D. and Miquel, J. 1986. In 'Free radicals, aging and degenerative disease', Alen R. Liss, N.Y.

17. Jung, S. W., Lee, N. K., Kim, S. J. and Han, D. S. 1995. Screening of tyrosinase inhibitior from plants. Korean J Food Sci Technol 27, 891-896.

18. Kim, E. Y., Baik, I. H., Kim, J. H., Kim, S. R. and Rhyu, M. R. 2004. Screening of the antioxidant activity of some medicinal plants. Korean J Food Sci Technol 36, 333-338.

19. Lee, J. J., Kim, A. R., Seo, Y. N. and Lee, M. Y. 2009. Comparison of physicochemical composition of three species of genus Angelica. Korean J Food Preserv 16, 94-100.

20. Li, S. P., Zhang, G. H., Zeng, Q., Huang, Z. G., Wang, Y. T., Dong, T. T. and Tsim, K. W. 2006. Hypoglycemic activity of polysaccharide, with antioxidation, isolated from cultured Cordyceps mycelia. Phytomedicine 13, 428-433.

21. Masamoto, Y., Ando, H., Murata, Y., Shimoishi, Y., Tada, M. and Takahata, K. 2003. Mushroom tyrosinase inhibitory activity of esculetin isolated from seeds of Euphorbia lathyris L. Biosci Biotechnol Biochem 67, 631-634.

22. Nita, A. and Young, A. R. 2005. Melanogenesis: a photoprotective response to DNA damage. Mutation Res 571, 121-132.
23. Oh, S. L., Kim, S. S., Min, B. Y. and Chung, D. H. 1990. Composition of free sugars, free amino acids, non-volatile organic acids and tannins in the extracts of $L$. chinensis M., $A$. acutiloba K., S. chinesis B. and A. sessiliflorum S. Korean J Food Sci Technol 22, 76-81.

24. Ohkawa, H., Ohishi, N. and Yagi, K. 1979. Assay for lipid peroxides in animal tissues by thiobarbituric acid reaction. Anal Biochem 95, 351-358.

25. Ok, M. and Cho, Y. S. 2005. Screening of fibrinolytic enzyme producing from microorganism in Korean fermented soybean paste and optimum conditions of enzyme production. Korean Soc Food Sci Nutr 38, 983-988.

26. Park, C. S., Kwon, C. J., Choi, M. A., Park, G. S. and Choi, K. H. 2002. Antibacterial activities of Cordyceps spp., mugwort and pine needle extracts. Korean J Food Preserv 9, 109-113.

27. Park, S. S., Ryu, Y. B., Lee, Y. H., Cho, Y. U., Cho, S. J., Choi, Y. J., Park, K. H. and Gal, S. W. 2007. Inhibition of melanin synthesis by mycelial culture broth of Paecilomyces japonica in the mulberry Leaf extract. J Life Sci 17, 816-821.

28. Plaa, G. L. and Witschi, H. 1976. Chemicals, drugs and lipid peroxidation. Annu Rev Pharmacol Toxicol 16, 125-131.

29. Swain, T., Hillis, W. E. and Oritega, M. 1959. Phenolic constituents of Ptunus domestica. I. Quantitative analysis of phenolic constituents. J SCi Food Agric 10, 83-88.

30. Szolomicki, J., Samochowies, L. M., Drozdzik, W. J. and Szolomicki, S. 2000. The influence of active components of Eleutherococcus senticosus on cellular defense and physical fitness in man. Phytother Res 14, 30-35.

31. Wong, S. F., Holliwell, B., Richimond, R. and Skowroneck, W. R. 1981. The role of superoxide and hydroxyl radical in the degradation of hyaluronic acid induced by metal ions and by ascorbic acid. J Inorganic Biochem 14, 127-134.

32. Yun, J. S. 2009. Pathomorphological peculiarity of dometic silkworm, Bombyx mori. infected with Cordyceps, Paecilomyces tenuipes. Korean J Pesticide Sci 13, 177-184.

33. Zhu, Q. Y., Hackman, R. M., Ensunsa, J. L., Holt, R. R. and Keen, C. L. 2002. Antioxidative activities of Oolong tea. $J$ Agric Food Chem 50, 6929-6934. 
초록:Cordycepin 고함유 Cordyceps militaris JLM0636 용매별 추출물의 이화학적 특성 및 항산 화 효과

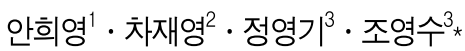

( ${ }^{1}$ 동아대학교 대학원 의생명과학과, ${ }^{2}$ 대선주조(주) 기술연구소, ${ }^{3}$ 동아대학교 생명공학과)

눈꽃 동충하초(PJ), 번데기 동충하초 $(\mathrm{CM})$, cordycepin 고함유 번데기 동충하초 $(\mathrm{CMa})$ 의 수용성, 에탄올 및 메탄 올 추출물의 생리활성 물질 분석과 항산화 활성 $(\mathrm{DPPH}$ free radical scavenging 활성, $\mathrm{Cu} / \mathrm{Fe}$-환원력, 간 조직 microsome 생체막 및 linoleic acid 과산화지질, Tyrosinase 저해활성, 혈 전용해효소 활성)을 측정하였다. PJ의 수용 성추출물 수율 $42.53 \%$ 이며 폴리페놀 화합물 함량 $2.72 \%$ 및 플라보노이드 함량 $1.73 \%$ 로 가장 높았고 $\mathrm{PJ}, \mathrm{CM}, \mathrm{CM}$ $\mathrm{a}$ 의 주요 지방산 성분으로 palmitic acid, oleic acid, stearic acid였으며, 주요 미네랄은 $\mathrm{K}, \mathrm{Mg}$ 및 $\mathrm{Ca}$ 으로 나타났 다. DPPH free radical scavenging 활성, $\mathrm{Cu} / \mathrm{Fe}$-환원력, linoleic acid의 과산화 지질 측정, Tyrosinase 저해 활성 에 의한 여러 항산화 활성은 $\mathrm{PJ}$ 가 가장 높았지만 $\mathrm{CMa}$ 가 $\mathrm{CM}$ 보다는 항산화 활성이 높은 것을 확인했다. 또한 간 조직 microsome 생체막 지질 과산화 억제활성은 $\mathrm{CMa}$ 가 가장 활성이 좋았고 혈전 용해효소 활성에서도 $\mathrm{CMa}$ 가 높은 혈전 분해능이 있는 것을 확인하여 향후 건강기능식품이나 기능성 화장품, 혈전용해효소 개발 관련 연구 의 기초자료로 활용될 수 있을 것으로 사료되어 진다. 